DOI: 10.1515/abcsj-2015-0002

\title{
Identifying with Dexter
}

\author{
JANNA HOUWEN
}

\author{
Leiden University
}

\begin{abstract}
Many contemporary high quality TV series tend to enable identification with protagonists who engage in morally dubious or outright abject acts. This essay takes Showtime's series Dexter as a pre-eminent and extreme example of this tendency, and explores how the viewer's identification with the serial-killing protagonist of the show is constructed and altered throughout several seasons of the series. In order to analyze the specific relation between Dexter and its audience, this essay first examines the more general possibility television series to produce firm identification of viewers with protagonists by comparing the format of the television series to two media that can be understood as its predecessors: literature and film.
\end{abstract}

Keywords: Television series, identification, Dexter

When a friend told me about Showtime's television hit series Dexter (2006-2013) before I had ever watched the show, she tried to convince me of the series' intricateness by saying: "It's a show about a serial killer... and you're on his side!" In her very short description, she managed to aptly point out one of Dexter's most surprising aspects. The series' narratives focus on the life of an unusual protagonist, who functions as the main internal focalisor and narrator of the stories as well. Dexter Morgan is not only a congenial forensic blood spatter analyst who works for the Miami Metro Police Department; he is also a cold-blooded, compulsive serial killer. However, in spite of the fact that it is unconventional for a criminal, vicious character to be the leading one in a story, the serial killer as protagonist is not an entirely new or unique phenomenon. Novels, films and film series such as Fantômas, American Psycho, and The Killer Inside 
Me each centre around the murderous impulses of their vicious leading character. ${ }^{1}$

Yet, although these films may inspire their spectators to become fascinated by the villains on screen, the serial killers in question are usually portrayed as evil, monstrous "others." Whenever stories on serial killers do allow their reader or viewer to briefly sympathize with the criminal protagonist, these moments are generally overruled by the urge to disidentifty with the abject criminals nevertheless. In the films Henri, Portrait of a Serial Killer (McNaughton 1986) and Monster (Jenkins 2003), for instance, the murderous impulses of the leading characters become more understandable to the spectator when the stories reveal that the two serial killers have been victims of dreadful physical violence themselves. However, their subsequent scary violent outbursts - of which innocent people are the victims - prohibit the film viewer from fully sympathizing with the murderers on screen.

Such restrain on sympathy is largely absent from Dexter. As opposed to most novels and films on serial killers, the Showtime series in question manages to raise feelings of unequivocal sympathy and empathy in the spectator for its murderous protagonist. After a couple of hours of watching Dexter, most viewers will indeed feel to be "on his side," as the series spurs the viewer to identify with Dexter Morgan in many ways. Because of this, the series works against the grain of conventional morality, which dictates, to put is simple, that murder is wrong. As Douglas Howard puts it: "Nothing should make serial killing okay, but, somehow, Dexter does" (2000: xv, my emphasis). ${ }^{2}$

What is more, the series does not only stand out for its forceful invitation to identify with a serial killer, it also forms a remarkable transition between different kinds of identification. As I will explain, the viewer's identification with Dexter is not a stable given, but an ongoing process which is altered, reinforced and reshaped by the series in the course of its development, throughout different episodes. In this essay, I investigate how this process of identifying with Dexter precisely proceeds when watching the series in question. How does Dexter evoke identification with Dexter?

I argue that this question cannot be answered without paying 
attention to the serial form in which Dexter's stories are told. The format of the television series - which has become increasingly popular over the last decade - offers unique possibilities in producing specific forms of identification with Dexter, the killing hero of the show. Before turning to the specific relation between the serial character of the narrative and the spectators' sympathy for the serial killing "night job" of its leading character, though, it is first necessary to reflect the relation between the television series and character identification in a more general sense. Dexter can be regarded as a pre-eminent and rather extreme example of a tendency that can be discovered in more recent high quality television series such as Shameless, Game of Thrones, and Breaking Bad as well: it fully applies the unique possibility of the television series to spur viewer identification with protagonists who engage in morally dubious or outright abject acts. Murder, assault, (drug)abuse, parental neglect, theft and drug dealing become "okay"- or at least harder to outright condemn - when it is almost impossible not to identify with a show's murderers (Dexter, Game of Thrones), thieves, addicts (e.g. Shameless, Nurse Betty, The Knick), criminals and dealers (e.g. Breaking Bad, Orange Is the New Black). In order to explain this remarkable ability of television series, I will compare the form and effect of TV series to the novel and the film two media to which the television series is very much related. Differences and similarities with particular forms and social functions of the latter two media can provide insight into the TV-series' propensity towards the stimulation of firm character identification.

\section{OMG! Rita Died! :'-( \#Dexter}

Word has it that when Dutch author Louis Couperus had the leading character of his novel Eline Vere (1888) die, people in Couperus' home town The Hague whispered to each other on the city's tramcars: "Have you heard? Eline is dead!" When Dexter's wife Rita died in the last episode of the show's fourth season, social media were blast with posts that are reminiscent of the responses to Eline's death 12 decades ago. Tweeting online instead of whispering on public transport, fans of the series would ask each other: "Have you seen the final episode? Rita dies!" 
The similarity between the overwhelming public response to the death of the two disparate fictional characters - one the female protagonist of a realist novel, the other a leading female character in a television series - is not a coincidence. Dexter and Eline Vere have one important thing in common: both have been issued in serial form. Like so many other $19^{\text {th }}$ century realist novels, Couperus' Eline Vere was initially released as feuilleton. Before it was published as a novel, the story on Eline appeared in a Dutch newspaper in 119 episodes. The aspect of seriality which contemporary television shows and $19^{\text {th }}$ century serial novels have in common, incites firm identification with the fictional characters of serialized stories. This effect, however, can best be explained by comparing the television series to yet another medium with which it is often compared: film.

In answering the question of why viewers of television series tend to become so emotionally attached to, and involved with, the leading characters of the show, many theorist have largely focused on the fact that series offer their spectators so much time with the fictional characters. Compared to the length of a conventional narrative feature film, the dozens of hours that are taken up by the average television series seem abundant. As television theorists such as Michael Porter (2002) and Jason Mittell (2006) have claimed, one of the main possibilities (and challenges) of the long-serie form is a degree of extended character depth which is unavailable within a two-hour film. Simply because of the extended duration of all of the episodes of a TV-series together, the television viewer can be provided with a great deal of insight into the complex lives and ever developing, layered personalities of fictional protagonists.

It should be noted here that the long duration of a series is not an automatic guarantee of developing, layered personalities: characters in series can remain "flat," unchanging and as repetitive as a serial narrative itself can be. Nor does duration operate alone when it comes to creating character depth: the complexity of protagonists is also expressed through other means which rely on formal aspects such as the subtlety of gestures, the graphic qualities of the image, active use of space, editing, music and intertextuality (none of which are unique to the TV series; many formal devices that aid the construction of complex characters can just as 
effectively be applied in a two-hour feature film). Yet, the extended narrative time which television series have at their disposal certainly enhances their potential to elaborately expose and explain complicated psychological states and/or existential alterations in protagonists. When series apply their abilities to provide insight into their characters to the fullest, they are likely to install an impression in the spectator of knowing the leading characters really well, which facilitates the viewer's identification with the characters in question.

As the narrative complexity, visual spectacularity and aesthetic appeal of contemporary television series have come to meet the quality of today's cinematic productions, some film critics and media theorists have chosen to refer to television series as "megamovies" (Canby 1999, de Bruin 2010). Although this definition rightfully emphasizes that contemporary TV-series are highly influenced by cinema, it overlooks the importance of the intermittences between the episodes of a series. ${ }^{3}$ Television series should not be regarded as extremely long movies which have been cut into episodes for convenience's sake. Although some of a series' narrative plots run through several episodes or even seasons, each episode tells one whole, complete story as well. In this sense, television series are less of an "indefinitely expandable middle" than soap operas are. ${ }^{4}$ Whereas the latter's story-lines never end, each episode of a television series offers a story which comprises a beginning, middle and end. Simultaneously, other story-lines are left open-ended until the season finale, or even until the series' final episode. In Dexter, many episodes for instance revolve around the protagonist's hunt on one of his victims, which he introduces at the beginning of the episode, follows throughout the episode, in order to finally kill him or her in the end. In addition, each season introduces one other serial killer, with whom Dexter is suspensefully involved throughout the duration of one season (which usually consists out of 12 episodes). Moreover, both episodes and seasons are spanned by the overarching, continuing narrative of Dexter's attempts to cover up his identity as a serial killer.

When it comes to identification, the intermittences between serial episodes - and the tension between closure and open-endedness which they comprise - are extremely important. Whereas the long duration of an 
entire series enhances the possibility of developing a high measure of character depth, the intervals between episodes further sustain the viewer's involvement with a series' protagonist(s). Although we generally do not learn more about the characters in question during these intervals, our identification with protagonists can grow stronger by the fact that we can reflect on the characters during the intermittences. As popular series are watched by many viewers at the same time, such reflections on a character's developments frequently take place in a social context. The previously mentioned example of the tweets on Rita's death already pointed out that social media can function as an important platforms in this respect. Yet, questions such as "Have you seen last week's episode of Dexter? Rita is pregnant! How is Dexter going to feel about this? What kind of dad will he become?" are also posed "offline," during lunch breaks, over coffee, or (as in the old days) on public transport. Such discussions do not only create social cohesion between viewers of a show; they also affirm and deepen the viewer's identification with on-screen characters.

It is important in this respect that, unlike the characters in films (which are, of course, also discussed during lunch breaks and the like), the protagonists of television series reappear on screen day after day or week after week. They do not only become parts of our daily lives because we discuss them with others in the breaks between episodes, but also because they reappear in our life - albeit on screen - for years on end. ${ }^{5}$ It is therefore not surprising that viewers of TV-shows often come to think of leading characters in series as good friends, as people they know through and through, or as parts of themselves that will be missed dearly when the characters in question die - or the series ends ${ }^{6}$.

This social aspect of character identification brings us back to the comparison with which this paragraph started out; the comparison with the $19^{\text {th }}$ century serial novel. According to TV-critic Charles McGrath, the television series is not merely similar to the serial novel; it has actually taken over some of the roles that books used to fill. In an article titled "The Triumph of the Prime Time Novel" (2000), McGrath argues that "inventive TV series, ... have become for our era the equivalent of the serial novel, unfolding epic stories installment by installment, and 
sweeping all of us up in shared anxiety and in a lot of group sighing and head shaking over what fate or ... the author has in store" $(244) .^{7}$ The critic in question draws the parallel between the realist serial novel and the TV series even further when he states that:

TV drama is also one of the few remaining art forms to continue the tradition of classic American realism, the realism of Dreisder and Hopper: the painstaking, almost literal examination of middle- and working-class lives in the conviction that truth resides less in ideas than in details closely observed. More than many novels, TV tells us how we live now. (244)

Although McGrath's argument can be criticized for being too sweeping (simply because there are so many exceptions to his rule, both in the form of novels and in TV series), the comparison between the realist novel and the television series is an interesting one with regard to the series that is the subject of this essay. ${ }^{8}$ Dexter meets McGrath's definition of realism as "literal examination of middle and working class lives," as its protagonist and main focalisor examines his social surroundings with the cold, "dissecting" look of a forensic investigator and serial killer. Being a sociopath, Dexter doesn't feel anything, so he claims. Therefore, social interaction doesn't come natural to him. He has to study social conventions and customs in order to "fit in." In season one, Dexter explains in voice-over that he actually still feels as he did when he was a teenager: he would prefer solitude. For, when he's alone, he doesn't have to act normal. "But what would people say?" the protagonist wonders. "Lives alone, quiet, keeps to himself." That won't work. "Might as well put a sign on the door that says; "Serial killer lives here."

So, in order to appear as normal as possible, Dexter secretly studies the people around him, most notably his colleagues at the police department, his (suburban) neighbors, and people in the streets of the large metropolis of Miami. ' Subsequently, he copies their "averageness," as well as their ordinary social habits. The serial killer for instance realizes that, as an adult man, he needs a girlfriend in order to appear normal. Therefore, he gets involved with Rita, a gentle yet psychologically damaged woman who is unlikely to see Dexter's dark side. Because of a troubled past with an addicted husband, all Rita wants 
is a normal life. "I've had enough excitement, thank you. I'll take boring. Average. Ordinary." Naturally, this appeals to Dexter, who wishes to cover up his true nature by acting as ordinary as possible.

Together with Rita, Dexter slowly builds such an ordinary life as the series progresses. In the course of the first four seasons, the couple moves in together, gets married, moves to the suburbs and has a baby. While living the (middle-class) American dream, Dexter incessantly studies his social surroundings with the detailed eye of a forensic expert, as well as with the occasional surprise which comes with his perspective as an outsider. The sociopath is baffled over and over when he discovers those aspects in "average" people which come close to his own dark side, that is: the bad, the ugly and the vile sides of human nature. When his colleagues for instance discuss how they would "pull a broncho" on women (yelling another woman's name during sexual intercourse), Dexter ironically remarks in voice-over how he often feels to be "missing some essential piece of the human puzzle. This is one of them." A similarly ironic remark is made by the protagonist when he goes on a date with Rita, and watches other people hitting crabs with mallets. While close-ups of chewing mouths, hitting arms and splintering crabs show us Dexter's focused point of view, his comment on the rather repulsive spectacle can be heard in voice-over: "Needless to say I have some unusual habits, yet all these socially acceptable people can't wait to pick up hammers and publicly smash their food to bits. Normal people are so hostile."

\section{A neat monster}

The three aspects which tie Dexter to the $19^{\text {th }}$ century realist novel namely, the predominance of Dexter's voyeuristic focalisation position within the series, his focus on the everyday habits of ordinary people, and the show's serial form of successive episodes - each play a vital part in the manner in which the series manages to construct and shape the viewer's identification with Dexter. First of all, Dexter's position as main character-bound focalisor in the series stimulates the viewer's identification with the serial killer simply because the possibility to look through a character's eyes creates the impression in the viewer of being in 
the character's shoes, so to speak. The mere fact of seeing things from Dexter's perspective will lead to the inclination of being (or rather; feeling) "on his side," even though his violent acts are condemnable.

In the series, Dexter's point of view does not only predominate because a great deal of images are sutured to his perspective through conventional cinematic editing techniques. Dexter's point of view attaches itself to many of the show's images because his voice-overs reveal that he is highly aware of his own "performances." Next to his observations of other people, Dexter is constantly looking at himself, as it were. Without human emotions as a guide in every day interactions, Dexter's daily life is a performance of ordinariness of which the sociopath himself is both the performer and the onlooking guard. As he puts it: “... I'm floating on the surface of my own life. Watching it unfold. Observing it. I'm the outsider looking in." As a result, the viewer of Dexter can only escape the protagonist's viewpoint in the scarce scenes in which Dexter himself is completely out of sight. For even images of Dexter can be understood as being focalized by Dexter, as he proves to be constantly observing himself.

In addition to the fact that Dexter's dominant position as an internal focalisor forms an invitation to the viewer to identify with him, the voyeuristic character of his point of view further seduces the spectator to side with the serial killer. As mentioned before, Dexter often comments on socially acceptable habits in an ironic way. Although his observations serve the serious purpose of not being exposed as a serial killer, Dexter's findings on human behavior are often lightheartedly mocking: "Want a real glimpse of the human nature? Stand in the way of someone's mocha latte." Whereas the distant, analytical point of view of a serial killer is potentially scary and abject, in Dexter, it is rather amusing. The mocking comments make Dexter an agreeable character: he makes us laugh, therefore we like him. In addition, the serial killing protagonist is engaging and sympathetic because he frequently comments on his own empathic and social shortcomings in a jocular way: "I can kill a man, dismember his body, and be home in time for Letterman. But knowing what to say when my girlfriend's feeling insecure... I'm totally lost."

However, in spite of his appealing sense of humor and amusing 
struggles with social conventions, Dexter's murderous impulses are rather off-putting. The viewer of the series is a visual witness to his violent attacks as well as cold-blooded killings. Especially in the first episodes of the series, the scenes which depict Dexter's well-prepared murders are quite shocking. The protagonist is shown to operate in an almost clinical manner. He ties his sedated victims to a table in a sterile "kill room" which is covered with plastic disposable sheets. When a victim wakes up from the anaesthetized state, Dexter prepares a slide with a drop of his victim's blood (his "trophy"), upon which he stabs him or her in the heart. These acts stand in the way of identifying with the otherwise amusing character. Yet, in the course of the first season, Dexter's kills become less rejectable, for two reasons. First of all, Dexter turns out to operate according to what he calls "the code." This code was set by his father, the only person in Dexter's life who saw his sociopathic nature. In order to channel his son's dark impulses, the father (a former cop) invented the rule that Dexter could only kill other murderers. Murderers, moreover, who have escaped punishment through the loopholes of the law, or who have escaped conviction due to lack of evidence. The code dictates, however, that Dexter collects sufficient evidence before he kills murder suspects, so as to prevent him from killing innocent people by mistake. In sum, Dexter kills other murderers. Serial killers, child molesters and murderous criminals who have escaped the law are tried and punished by Dexter's "knife of justice." "I have standards," the protagonist declares. "I am a neat monster."

Because of Dexter's "standards," his murders become more acceptable in a moral sense. For, killing people who have killed themselves certainly is not as bad as killing innocent people. In an article on Dexter and philosophy, theorist Susan Amper has aptly pointed out that, although Dexter's murders are still not entirely right (as they are still cool-blooded murders, as well as violations of the law "that protects us all"), many viewers feel that Dexter's punishment of the guilty somewhat justifies his illegal acts (111). As Amper and others have noted, Dexter makes a strong plea to a utilitarian perspective. ${ }^{10}$ Philosopher Matthew Brophy (2010) explains as follows: 
The ... ethical vindication of Dexter's killings arrives via utilitarianism: an act is ethical if it maximizes overall happiness. An action that makes many people happy is a good one, even if it makes people unhappy. Killing society's predators, then, might be morally good by preventing the future torture and slaughter of innocent people. Utilitarianism denies that any act is intrinsically wrong, even killing: an act is only instrumentally wrong if it fails to maximize happiness. Simply phrased: the ends justify the means. (82)

Dexter's appeal to utilitarianism has not been received with undivided critical acclaim. Yet, for most viewers, the fact that Dexter is a murderer who kills murderers means that "being on his side" is not an entirely immoral thing to do. Therefore, identification with the sympathetic serial killing hero is no longer "wrong."

What is more, near the end of the series' first season, Dexter's serial killings are not only made justifiable; they are also made understandable. During the first ten episodes, nor Dexter, nor Dexter's spectator have a clue as to why the protagonist has the irresistible need to kill other human beings. In episode eleven, however, Dexter suddenly experiences an elongate flashback of a memory he has repressed for decades. The gruesome flashback reveals that Dexter once witnessed how his mother got slaughtered with a chainsaw. From this point onwards, Dexter understands his need to kill as result of this experience. In the eyes of the protagonist, his identity as a serial killer was created that day. "I was born in blood," Dexter concludes.

The suggestion that Dexter's kills are reenactments of the above mentioned traumatic childhood experience, provides the viewer with another reason to put any objections against identification with the killer aside. For the cold-blooded perpetrator turns out to be a victim, too. A victim who we may pity, and with whom we may empathize. His guilt, moreover, can now be displaced to, or at least shared with, the people how have caused his dark side. Not Dexter himself, but his mother's murderers are to blame for his acts, as they damaged Dexter's psyche so bad that he cannot help being a monster. A neat monster. An innocent monster. Almost. 


\section{The monster next door}

The above mentioned explanation of Dexter's cruel nature changes the manner in which the spectator identifies with the character. During the first episodes of the show, the viewer may identify with Dexter because of his amusing point of view and engaging struggles with "normal" human interaction. Yet, the serial killer remains an other, an outsider with an unfamiliar mind-set, and with abject impulses. Even though the protagonist himself may at times suggest that there are some surprising similarities between "normal" people and "evil" serial killers ("normal people are so hostile"), it is hard for most viewers to identify with Dexter on the basis of similarities. In spite of all the differences between individual members of the series' audience, it is safe state that during the first season, Dexter is not like "us." He is not one of us, nor is he someone we could easily be, or easily become.

This changes when Dexter's serial killing aptitude turns out to be caused by a horrible crime. It appears that the serial killer is not inherently bad; he is not vile by nature. His evil deeds are rooted in an event so traumatic, that it would have altered all of us for the worst. The inescapable depraving influence of Dexter's childhood bloodbath is all the more sustained in the series by the fact that another witness of the massacre - Dexter's older brother Rudy - also turns out to have become a serial killer. This suggest that we, as viewers, would also have become serial killers, had we experienced such violent trauma. Therefore, Dexter can no longer be regarded as wholly other, as someone we could never be or become. In the course of season 2 and 3, Dexter's otherness diminishes even further. As a result, the viewer's identification and "feeling with" the protagonist will be based ever more on similarities. Before further explaining this transition, let me first define the two different forms of identification which are stimulated by the series.

In The Threshold of the Visible World (1996), Kaja Silverman argues that identification takes on two forms. One form involves identification on the basis of a (projected) likeness. In a slightly "cannibalistic" process, the other is taken into the self. Features of the other that are similar the self are enhanced in the process, while features 
that remain irreducibly other are cast aside or ignored. As a result, the other "becomes" or "becomes like" the self. Hence, this form of identification, which Silverman terms idiopathic, relies on seeing the other as similar to the self. Heteropathic identification, on the other hand, does not rely on likeness. It concerns the act of identifying with the other as other. In the case of heteropathic identification, the self doing the identification takes the risk of - temporarily and partially - "becoming" like the other. ${ }^{11}$ According to Silverman, this can be risky and dangerous, but also exiting and potentially enriching.

Dexter first seduces its viewer to the "dangerous" and "risky" act of heteropathic identification with a serial killer. By presenting Dexter's killings as justifiable and understandable, the ethical risk of identifying with a serial killer is played down. Hence, the spectator can uninhibitedly identify with Dexter as other. However, this form of identification slowly changes into idiopathic identification as Dexter becomes more "normal" during the first 4 seasons. First of all, as mentioned before, the introduction of his traumatic past suggests that he is not an inhuman aberration, but a human being like the rest of us - albeit a severely damaged one.

Secondly, Dexter's observations of ordinary life are shown to gradually pay off as the series' seasons succeed each other. The serial killing hero for instance manages to perform his role as Rita's loving boyfriend so convincingly, that she is willing to marry him. And although Rita's pregnancy wasn't planned - and scares Dexter to death (no pun intended) - it provides Dexter with the ordinary role of suburban dad. Moreover, in spite of the fact that the sleepless nights with his newborn son keep Dexter away from his beloved kill room, he performs his traditional tasks a head of a nuclear family with a convincing measure of dedication. What is more, the protagonist very well realizes that his newly established ordinary life functions as a great cover for his dark side: "Family man. Husband and father. Sounds so upstanding; harmless. Much better than lives alone and keeps to himself."

Dexter's above remark show that he is still self-consciously performing his identities, even though he has established his normality to the outside world. However, the protagonist doesn't merely appear 
normal to the outside world by exchanging his life as a bachelor for a conventional, middle class, settled down family life. He becomes more normal on the inside, too, as he slowly develops some of the feelings and emotions which are proper to a father and a husband. First of all, he clearly loves his son Harrison. Dexter repeatedly expresses his desire to protect him, as well as anxieties about raising him. He is terribly afraid that his own identity as a sociopath will affect Harrison, who means the world to him. In addition, Dexter proves to feel very protective towards Rita when he fears that she might be in danger because of his "job" as a serial killer. What his more, he worries about her finding out who he really is for unselfish reasons: Rita would be devastated. When Rita dies, Dexter mourns. Moreover, he confirms his own development towards humanness when he remarks on Rita that: "She had a big heart, big enough for the both of us, had to be, I wasn't even human when we first met." 12

As Dexter turns into a more or less normal, average person with actual human emotions, the viewer of the series is enabled to identify with him on the basis of similarities. He is no longer an "other," but a person who becomes like us. At this point, the murderous impulses which set him apart from the average viewer can easily be cast aside as a marginal deviation from his otherwise human disposition. We, as viewers, are not so much on his side anymore; Dexter has now become one of us. The viewer can take him into the self, as Silverman would put it. In the course of Dexter's first five seasons, identification thus slowly changes from heteropathic to idiopathic. Moreover, as I will explain below, this transition is all the more enhanced by the serial form of the television show.

\section{The serial viewer}

The form of the television series is very compatible with the serial character of Dexter's killings. Especially in the first season, the successive episodes follow Dexter's successive murders: each new episode tells the story of a new kill. These stories, moreover, are alike. First, Dexter starts to suspect someone of murder. His desire to kill grows. So, he starts to 
collect the evidence he needs in order to be absolutely certain of his victim's guilt. After that, Dexter follows and captures his prey, upon which he kills them in a well-prepared "kill room." The final scene often shows how Dexter steers his boat into the wide, desolate ocean. With a relaxed attitude, the serial killer swings the dismembered body parts of his recent victim into the ocean. All is well that ends well. Dexter is satisfied - but only partially and temporarily. For in the next episode, he will turn out to need another kill. The search for a new, slightly different, yet guilty victim begins all over again.

The serial killer's pattern of repetition with only slight differences perfectly matches the iterative narrative character of the television series in general. However, this narrative pattern of the series does not only follow or comply with Dexter's string of murders. The form of the series has a performative effect which shapes and reinforces the viewer's idiopathic identification with Dexter. In each episode, Dexter's desire to kill grows and rises together with the suspense of the story. Will his victim turn out to be really guilty? Will Dexter manage to kidnap his target without too much of a struggle? What if he gets caught? Will he manage to finish off the guilty bad guy before Rita starts to wonder where he is / the nosy neighbor discovers the kill room / the patrolling police officer becomes suspicious? Because of an abundance of suspenseful moments throughout each story, the viewer is likely to feel relieved when Dexter finally kills his victim, and soothed by the images of wrapped-up body parts sinking into the depth of the Atlantic Ocean.

As the viewer of Dexter grows familiar with the narrative iteration within the series, she can anxiously long for the following episode. What kind of vicious wrongdoer will Dexter target next time? What is more, this desire for a next episode is stimulated by the fact that the episodes of a series never offer full narrative closure. Although the stories of Dexter's kills are wrapped up (in plastic, one might say) in each episode, other story lines continue. Therefore, the viewer's desire for narrative closure is never fulfilled entirely.

Tania Modleski would argue that the cause of the viewer's desire to watch yet another episode on the serial killing hero should not only be sought in her curiosity as to "what will happen next." In an article on soap 
operas, Modleski argues that the spectator's compulsion to repeatedly tune in to soap operas in order to watch the same story of the same villain(ess) over and over again, can be explained by way of Freud's theory of repetition compulsion. Freud, Modleski points out, saw the compulsion to repeat as resulting from an individual's attempt to become an active manipulator of his/her own powerlessness. Speaking of the child's fort-da game, Freud notes:

At the outset he was in a passive situation - he was overpowered by experience; but by repeating it, unpleasurable though it was, as a game, he took an active part in it. These efforts might be put down to an instinct for mastery that was acting independently of whether the memory itself was pleasurable or not. (10)

According to Modleski, the spectator of soap operas constantly returns to the same story, and repeatedly identifies with the same main character, because this repetition allows her to achieve - temporarily - the illusion of mastery denied to her in real life (34). Especially vile main characters who try to gain control over their own passivity in the story world are appealing in this respect, as these characters act out the spectator's fantasies of power.

Whereas Modleski's argument concentrates on the power(lessness) of the female viewer of soap operas, the viewer of Dexter can be said to be powerless in the face of injustice. Criminals escape the law, yet the law forbids us to take the law into our own hands. Dexter does take the law into his own hands. In this respect, he may be acting out the viewer's fantasy of power.

One way or another, Dexter's serial form can be said to install a compulsion to repeatedly watch the show in its viewer; either because the serial iteration appeals to the spectator's fantasy of power, or simply because it stirs her curiosity for new and open-ended stories - or both. When it comes to idiopathic identification, it is especially interesting that through this desire for the next episode, the viewer of Dexter becomes slightly similar to Dexter. It goes without saying that the serial killer himself is driven by the compulsion to repeat. What is more, the idea that such repetition compulsion should be understood as a subject's attempt to 
become an active manipulator of her/his own powerlessness in an unpleasurable, overpowering situation makes a lot of sense when it comes to Dexter. ${ }^{13}$ In sum, the protagonist incessantly longs for more blood, over and over again - and so does the spectator. As the show progresses, the series' viewer grows an insatiable desire for more stories on Dexter's bloody businesses - over and over again.

Before, I explained that the series gives rise to idiopathic identification with its sociopathic character when Dexter becomes more "normal", and hence less "other", during the first five seasons. In addition to this, however, the viewer is also invited to identify with the serial killer on the basis of similarities because she herself becomes - or is made more like the "other" by the serial narrative. Not because she is invited to imagine herself in his place through heteropathic identification, but because she, like Dexter, actually falls prey to repetition compulsion when watching the series. Therefore, ideopathic identification with Dexter is not merely the cause, but also the result of that fact that the viewer becomes like Dexter by watching Dexter.

\section{Notes:}

${ }^{1}$ The three titles mentioned here have in common that they were all first published as novels, and were subsequently released as films. The Fantômas novels (1911-1913) were written by Pierre Souvestre and Marcel Allain, the film series were directed by, among others, Louis Feuillade (1913-1914) and JeanLouis Buñuel (1979). The novel American Psycho (1991) by Bret Easton Ellis was released as film in 2000 (dir. Mary Harron). The Killer Inside Me was written by Jim Thomson in 1952. The cinematic adaptation of the novel was directed by Michael Winterbottom (2011).

${ }^{2}$ The fact that Dexter manages to produce identification with a serial killer has incited fierce critiques on the (im)morality of the series itself. Although I will not leave the issue of morality entirely untouched, this paper first of all addresses the question of how the series in question produces identification with a serial killer. ${ }^{3}$ Film and television scholars have mainly located the influence of cinema on the television series in the artistic application of the cinematic medium. Kristin Thompson has for instance argued that especially norms from art cinema have been imported onto the small screen. For this reason, she suggests thinking of TV-series such as Twin Peaks and The Singing Detective as "art television" (2003: 72). Jason Mittel, in addition, draws a parallel between the innovative film narration of "puzzle films" like Memento and Adaptation, and the narrative complexity which characterizes so many popular television series today. What is 
more, the latter theorist provides a tentative explanation for cinema's influence on television series when he points out that "many of the innovative television programs of the twenty past years have come from creators who launched their careers in film, a medium with a more traditional cultural cachet" (30). Although I agree with Thompson and Mittel in that the influences of so called art-house cinema can readily be discovered in many TV-series, I hold that the genre of the TV series has not been left untouched by the visual spectacle and narrative conventions which dominate mainstream cinema either. In addition, I claim that when the influence of art cinema on television series is taken into account, it is important to note that the norms of art cinema are generally imported into popular, mainstream television series. Thompson's definition of "art television" overlooks the fact that many innovative television series are not regarded as artistic pieces by their viewers. In spite of their incorporation of artistic cinematic devices, most TV series function as popular, "primetime" entertainment.

${ }^{4}$ The idea of the soap as ongoing middle was put forth by TV-critic Dennis Porter, who remarked that "If ... as Aristotle so reasonably claimed, drama is the imitation of human action that has a beginning, middle, and an end, soap opera belongs to a separate genus that is entirely composed out of an indefinitely expandable middle" (Porter in Modleski, 1979: 12).

${ }^{5}$ Online streaming services such as Netflix have made the time gaps between serial episodes less inevitable. Yet, even binge watchers need to take breaks and wait for new episodes once in a while. Although one season of a show can be watched in one day, it is hardly possible to watch several seasons of one series without interruption. In addition, the intermittences between the releases of a series' seasons can only be circumvented by viewers who watch a show when it has concluded its final season.

${ }^{6}$ For further discussions and examples of the ways in which viewers relate to the protagonists of TV-series as friends, family members or beloved ones, see William Evans (2005) and Charles McGrath (2000).

${ }^{7} \mathrm{McGrath}$ further explicates his view in a discussion of the television show N.Y.P.D.Blue: "The show uses time in the way serial novels used to, incorporating the intervals between installments, and the tension between what we've learned and what we fear or hope, into the experience of the story itself. I had several morning after conversations last year with a friend of mine, another faithful viewer, about whether or not Simone's new girlfriend, Detective Russell, was a secret alcoholic- discussions not dissimilar, I imagine, to the ones serial readers must have had in 1841 while they waited for the news about what had happened to Dicken's little Nell" (McGrath 250).

${ }^{8}$ Notwithstanding the "sweepingness" of McGraths argument, his statement is not entirely unfounded. It is remarkable how many TV-series focus on working, middle-class people. In addition, compared with mainstream films, popular TV series more frequently represent marginalized social groups such as people of color and homosexuals. According to McGrath, the more "daring" realist character of TV series could be explained by the fact that, in spite of its commercialism, TV shows are less "under the thumb of the money men" than 
either the movies or the Broadway theatre, if only because with any given episode there is so much less at stake financially (McGrath 243).

${ }^{9}$ This voyeurist viewing position of the series' main focalisor can in itself be regarded as yet another analogy between Dexter and the project of $19^{\text {th }}$ century realism. In Spectacles of Realism (1995), Christopher Prendercast has convincingly argued that realism is based on a specific, voyeurist mode of looking. In addition, many of the themes which are typical to both realism as a literary movement and realism as a mode of representation hold central positions in Dexter. Next the topic of ordinary American daily life, the series revolves around the theme of sexuality (Dexter feels threatened by female sexuality), adultery (both Dexter and Rita have an affair), the city (Dexter moves through all social layers of Miami), and questions on nature and nurture (Dexter was not raised by his biological parents, and worries about his son; will he be "normal"?). Finally, it almost goes without saying that death is an important theme within the series, as it is the main obsession of the serial-killing protagonist. Throughout the successive seasons of the series, Dexter tries to come to grips with these matters of sexuality, adultery, nature, nurture, and death. All of these topics, moreover, are essentiality ungraspable and inexplicable to him, and escape his control time after time.

${ }^{10}$ This perspective has its roots in the writings of philosophers such as Jeremy Bentham (1748-1832), James Mill (1773-1836) and John Stuart Mill (1806).

${ }^{11}$ See also van Alphen (2008: 95).

${ }^{12}$ Although Dexter's facade of ordinariness slightly decreases when he loses his role as head of a nuclear family after Rita's death in season 4, his capacity to feel genuine human emotions, to care for and empathize with others, increases in the seasons that follow. The series' very last scene is a beautiful finale of this process of humanization, as well as an intricate reversal of the character's situation in season 1. The ending shot of Dexter reveals that the protagonist is no longer a sociopath who hides the fact that he lacks feelings by constructing a social life for himself while faking human emotions. Instead, the leading character turns out to have chosen an isolated life in the end. Living alone, keeping to himself, at last. Yet, it is no longer self-evident that a heartless serial killer lives in the recluse's logger cabin - as Dexter himself would have it in season 1. For his final choice to retreat from the world and abandon his girlfriend and son was made out of love: "I destroy everyone I love. But I can't let that happen to Hannah and Harrison. I have to protect them from me."

${ }^{13}$ For a more elaborate psychoanalytical discussion of Dexter's compulsions and characteristics, I refer to Beth Johnson's "Sex, Psychoanalysis, and Sublimation in Dexter" (2010).

\section{Works Cited}

Amper, Susan. "Dexter's Dark World: The Serial Killer as Superhero.” In Serial Killers and Philosophy. Ed. Sara Waller. Malden:Blackwell, 2010. 103- 
114.

Bruijn, Peter de. "Beter dan Film." NRC Handelsblad 5 November 2010.

Canby, Vincent. "From the Humble Mini-Series Comes the Magnificent Megamovie." New York Times 31 October 1999.

Brophy, Matthew. "Sympathy for the Devil: Can a Serial Killer Ever Be Good?" Serial Killers and Philosophy. Ed. by Sara Waller. Malden: Blackwell, 2010. 78-89.

Freud, Sigmund. Beyond the Pleasure Principle. First published in German in 1920. Trans. John Reddick. London: Penguin Books Ltd, 2003.

McGrath, Charles. "The Triumph of the Prime-Time Novel." Television: The Critical View. Ed. by Horace Newcomb. New York: Oxford U.P., 2000. 242-252.

Mittell, Jason. "Narrative Complexity in Contemporary American Television." The Velvet Light Trap 58 (2006): 29-40.

Modleski, Tania. “The Search for Tomorrow in Today's Soap Operas: Notes on a Feminine Narrative Form." Film Quarterly 33.1 (1979): 12-21.

Porter, Michael J., D.L. Larson, A. Harthcock, and K.B. Nellis. "Re(de)fining Narrative Events: Examining Television Narrative Structure.” Journal of Popular Film and Television 30 (2002): 23-30.

Silverman, Kaja. The Threshold of the Visible World. New York: Routledge, 1996.

Thompson, Kristin. Storytelling in Film and Television. Cambridge, MA: Harvard U.P., 2003. 